\title{
Do not let him die: Celebrating the legacy of Es'kia Mphahlele
}

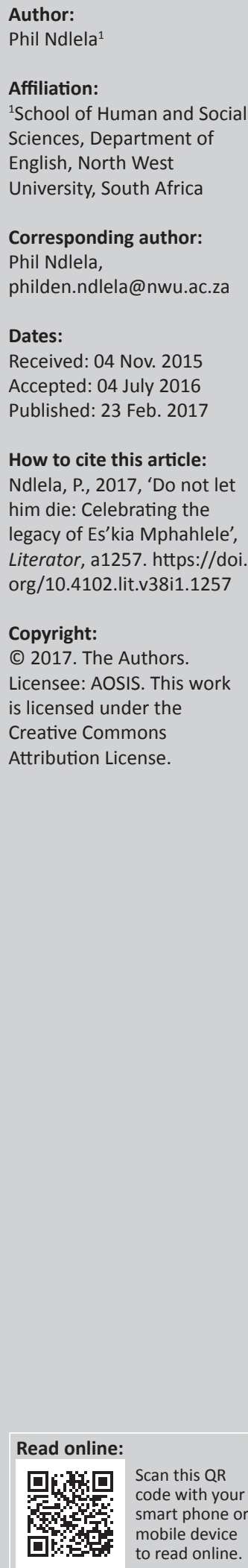

October 27, 2008 marked the passing on of the world-renowned Man of Letters Professor Ezekiel (later Es'kia Mphahlele). This essay is a journey back that retraces the indelible footprints and immense contribution of this cosmopolitan gentle giant of African letters. I will revisit some fragments from his eclectic oeuvre, which I regard as a treasure trove and a national archive that defines his legacy. I will also bring to light one of his lesser known works - a poem entitled: 'To You My People', which was published in the now defunct literary journal, New Classic, in 1987.

In my view, Mphahlele was one of the twentieth century's foremost intellectuals, writers, humanists and teachers. Like his African-American counterpart, W. E. B. Du Bois, he was a man of firsts. Mphahlele became the first black person in South Africa to obtain an MA in literature from the University of South Africa - Cum Laude. His MA dissertation was subsequently published as the seminal The African Image (1962). On the other hand, Du Bois's magisterial work, The Souls of Black Folk, remains one of the most cited works in the African-American literary and political landscape.

Mphahlele's oeuvre was eclectic and his autobiography, Down Second Avenue (2004), instantly catapulted him to literary prominence - a prominence confirmed by his work of African literary history and criticism, The African Image (1962), Voices in the Whirlwind and Other Essays (1967), and his novel, The Wanderers (1971), which earned him a nomination for the Nobel Prize for literature. This was followed by other works such as: Chirundu (1980), Father Come Home (1984), Afrika My Music (Mphahlele 1984a), academic essays and public addresses. He tenaciously fought and advocated for the centreing of African literature as he felt that it was not accorded due recognition during his tenure at the then conservative University of the Witwatersrand. His pioneering place in African literature in English needs to be applauded. Research shows that even though Mphahlele left behind volumes of eclectic scholarly and creative work, South Africa and the world have not accorded him the sort of respect that is due to him. In an article entitled, 'The Humanism of Ezekiel Mphahlele', Samuel Asein (1980) wrote as follows:

There are a few African writers who have contributed much to the development of African literature and have little written about them. Of the few, the black South African writer, Ezekiel Mphahlele, stands out rather pathetically as much neglected, generally underestimated and often misjudged. (p. 38)

Asein's concerns cannot be dismissed as obsolete or unwarranted. They are as relevant today as they were when he conceived them. There is still a lot of work to be done by us academics in terms of giving due prominence to Mphahlele's immense literary and scholarly output by way of prescribing it in our literary studies courses at universities. Even the laudable initiative that culminated in the establishment of the Es'kia Institute was his brain child. It would be interesting to know the number of departments of English literature that prescribe and teach Mphahlele's works in South Africa. It would also be interesting to know how many of our Provincial and National Departments of Education have included Mphahlele's works in the curriculum. In his highly acclaimed book, Race Matters, Cornel West (1993) cautions us about the pitfalls of neglecting our collective leadership responsibilities to the younger generations:

Quality leadership is neither the product of one great individual nor the result of odd historical accidents. Rather, it comes from deeply bred traditions and communities that shape and mould talented and gifted persons. Without a vibrant tradition of resistance passed on to new generations, there can be no nurturing of a collective and critical consciousness - only professional conscientiousness survives. (p. 37)

The crucial points that Cornel West is raising in this extract are as relevant to America as they are to post-apartheid South Africa today. Mphahlele was the sort of man who seamlessly found the synergy between his writings, teaching and political activism - he was no fence-sitter. His active involvement in the campaign against the imposition of Bantu education in the 1950s in South Africa is concrete evidence of his not being a fence-sitter. His writings are testament to the fact that 
he knew he had a responsibility to the broader society and entire human race. In the Afterword to Alfred Hutchinson's (2006) autobiography, Road to Ghana, Mphahlele retraces his political odyssey and offers invaluable insights on how his activism and social consciousness cost him his true passion, teaching in the land of his birth:

I had first met Alfred Hutchinson in 1952. Three teachers, myself included, had been dismissed from working in a high school in Orlando East-now part of Soweto-and further banned from teaching anywhere else in the country. We had been organisers in the union, where we were officials, to resist so-called 'Bantu education'. This was a move by the Government to halt the progress made at the time by African students. Our curricula had been the same as for whites, even though we attended separate schools. Bantu education was especially tailored to be inferior and therefore to change all that.

Generally, the new features would include 'Bantu folklore' and instruction in the mother tongue through to matriculation. There were no text books yet in African languages for the whole range of high school grades. Pupils had revolted and boycotted classes. (p. 199)

In his collection of essays Voices in the Whirlwind, Mphahlele (1967) provides further evidence of his being arbitrarily jettisoned from his calling:

\begin{abstract}
After us, several hundred other African teachers were summarily banned from teaching when the Bantu Education Act came into force, incorporating all the principles in the Commission's recommendations. We could not appeal to any Court of Law. A black teacher, even in his private capacity, is no longer allowed to write or utter any kind of criticism whatever of public servant of any rank. (p. 211)
\end{abstract}

This short sightedness and seeming paranoia on the part of the then advocates of Bantu education - an ill-conceived and segregationist kind of policy - would inevitably result in some sort of haemorrhage or brain drain, and the black child would be the obvious loser. Valuable human resources would be lost because of this controversial Act.

His not being a 'fence-sitter' and active involvement in South African struggle politics comes through in the following excerpt from Down Second Avenue (2004):

In the year that I joined the African National Congress (ANC), the Bantu Education Act arrived in the African primary school, about the same time, Sophiatown, one of the only three freehold townships in Johannesburg for Africans, was being removed, because it was in a 'white area'. I reported these events for DRUM. On both occasions, the African National Congress was caught with its pants down. The leadership had never really interested itself in educational and cultural matters as an important flank to its activities. All its time had been taken up in organisational work around purely political ideology. Resistance to these two measures failed. Haphazardly, the ANC tried to jolt the morale of the masses by means of slogans... on the boycott of schools and Bantu Education the ANC leadership was terribly divided and confused. The boycotters did not reckon with the vicious circle that makes it imperative for working class parents to leave their children in the care of a school during the day, and that several months are needed to prepare the minds of parents about what Bantu Education means in the classroom, as a tool of oppression. (pp. 181-182)

The above extract is quintessential Mphahlele - it is forthright, bold and courageous. It also shows that he was neither an ideologue nor a blind follower. His direct and principled involvement in the struggle did not diminish or blur his vigilance, analytical disposition and independence of mind. One of the most admirable qualities of Mphahlele's character is that throughout his career he remained steadfast and true to his convictions. There is palpable scholarly documentary evidence to buttress this point. In an article entitled, 'Es'kia Mphahlele: Writer, teacher and teller of truth', which was published in the Sunday Times by one of his former students at the University of Denver's Creative Writing Programme, Professor Njabulo Simakuhle Ndebele (2008) after his passing on, wrote:

For Mphahlele, battling against apartheid seemed to be a struggle of personal fortitude against relentless collective suffering. Stand up against Bantu education, even if it cost you your teaching post, then start again and learn a new career in journalism. Muster discipline and obtain three degrees by correspondence, obtaining your MA with distinction through a seminal dissertation that became The African Image (1962). Running through Mphahlele's life is a strong strand of an inner life that gave him independence and a sense of personal stability way out of the reach of government, political organisations and public fashion. He cultivated for himself the vital autonomy of the artist and the educator in a society that valorised only politicians. (p. 34).

His expulsion from teaching eventually forced him into voluntary exile and he wandered into countries such as Lesotho, Nigeria, Zambia and the United States, to mention but a few. At a time when it seemed fashionable to blindly romanticise and exalt exile, Mphahlele took a rather different angle. In the extract that appears below, home and exile are juxtaposed and the picture that emerges is replete with paradoxes and incongruities. We do well to quote Ndebele (2008) here: Many years later, what Mphahlele came to call 'tyranny of place' - that irrepressible hold or pull that one's roots seem to have on one self, beckoned him home. The smells, sounds and sights of place dimmed by time in exile led to his desire for sensory reinvigoration, it overcame any doubts he had of returning home before the end of apartheid. Place, according to Mphahlele, assigns identity. It encircles one with human and physical connections. It tests you. It protects you. It exposes you to danger.

It curses and blesses you. And then it follows you unrelentingly with your memories of it. And when the memories begin to fade in exile, you obsess about how to get them back... yet there was both at home and in exile, much to kill the spirit. If apartheid destroyed black families, exile did not guarantee that Mphahlele could hold his together. If being in South Africa consigned you to a provincial parochialism, travel in exile opens up new worlds while simultaneously conveying the sense of being rootless. At some point, the desire for steadiness, 
definitiveness and being rooted became overwhelming. He had to decide. Whether the world would like it or not was secondary to the conviction behind that decision. He returned home. But how could he live with himself? Public, personal testimony was his chosen method to authenticate himself. In this very special sense, he preceded the truthtelling of the Truth and Reconciliation Commission (TRC) for many years.

He acknowledged that his decision might look like a betrayal. $\mathrm{He}$ admitted that fading memories threatened his imagination; that he yearned to teach South African students and mentor them through his world of experience. The Wanderers (1969), Father Come Home (1974) and Chirundu (1989) testify to his many restless struggles. In the face of such voluntary truth-telling, whoever was not willing to agree with him could not ignore the solid credentials of his honesty. (p. 34)

Once a teacher, always a teacher. Mphahlele's voluntary 'truth-telling' - to cull a phrase from Ndebele - is probably what is missing now in the country's body-politic. At a time when prominent people in leadership positions resort to dogged denial of the obvious as a survival and longevity strategy to stay in office, Mphahlele's open admission to what could possibly be interpreted as an act of betrayal on his part by some is remarkable, instructive and courageous. Education, curriculum content review, freedom of expression, Afrikan Humanism and the myopia of sectional politics were recurrent motifs in Mphahlele's writing and scholarship.

In an article titled, 'Africanising South African Education', which is published in his collected works, Es'kia Continued (2005), he notes:

Even more than simply the inferiority of standards that apply to black education, the fact of irrelevance has caused the present revolt. The matter of self-discovery and being has never been a feature of the present system. Nothing in it has to do with our condition as black people; it says nothing about the world the school child returns to after school: Poor living conditions, poor transport, low wages, dwelling houses that are matchboxes, steaming with body heat on hot or rainy days, cheerless in the winter time; lack of social amenities, and so on... I am trying to reveal by implication how Eurocentric education is for both Whites and Blacks in this country. It is pathetic to observe a matric class battling with Shakespeare's language, with a Elizabethen comedy, both so far from their experience while completely ignorant about the literature of their own subcontinent, let alone the rest of the continent. Indeed I would recommend that departments of English be scrapped and made departments of literature. African literature should cease to be an 'option' for second-year and Honours students. British, American literatures, works translated into English, can be brought in during third year. (pp. 171-173)

In this excerpt, Mphahlele speaks to a post-apartheid educational landscape that continued to be glaringly racialised, inequitable, fragmented and Eurocentric in orientation. Not only was he being critical of it - he also proposed workable and practical solutions and corrective measures that would make it viable and sustainable. Have we heeded his advice? Some of the weaknesses and pitfalls he highlighted seem to have remained with us more than twenty years after the attainment of democracy.

The recent countrywide university students-led upheavals are a manifestation of an educational system that is crying out loudly for visionary leadership and meaningful transformation. Some of the myriad concerns that were raised by the recent 'Fees Must Fall Movement' spoke directly to germane and critical curriculum content issues. Some students were calling for the Africanisation of the curriculum a sort of intervention they regarded as long overdue in postapartheid South Africa. It is sad that the university students' legitimate and valid concerns about our largely skewed higher education landscape were met with callous and brute police and security forces violence. Freedom of thought and speech as well as institutional autonomy were considered sacrosanct by Mphahlele (2005). What follows below are fragments from a public address entitled, 'Subverting Efforts Towards Academic Freedom: The Travails of African Universities', which he delivered at the then University of the North:

'Choose anyone you like that I approve of'. That is the message that comes to us. Whatever happened to the democratic ideal of - to use the now-moth-eaten phrase - 'consultation and consensus?' Whatever happened to national justice, which we often resort to when the letter of the law becomes too harsh. It is evidently going to be a long time before we summon up the will to re-educate ourselves for non-partisan, nation-building institutions that transcend resistance politics that virtually call for blood-exacting oaths and loyalties, inspiring purposeful manoeuvres and sharpening of the long knives for a takeover of some sectarian turf. We shall need to take a leap from a sectional activist mindset, in all spheres of our life, to a realization that there are several of us in this country who have much to contribute to education, even if we don't fly a banner that identifies our fondest political or religious affiliations. Why do I have this uneasy feeling that the confirmation of appointments of executive officers in certain universities by higher authorities who have a political axe to grind in the narrowest sense of the expression is telling us something about the shape of things to come? Or is it just the fear of a naive academic?... Although the World Bank report does not come out to say so in so many words, independence began to lose its glamour after a decade.

Members of the ruling parties have been busy collecting the spoils garnered from favours sold to foreign investors. Being the sensitive antenna of their people's consciousness, and being best able to analyse, interpret, replay the corruption and cause more muck to resurface, academics and writers came down scathingly on government leaders, individually and in the public service. They had all the artillery they were skilled in using: fiction, news reporting, poetry, prose, satire, theatre. The report indicates that when government took notice because of the vocal indignation among those who could read and spread the bad news, they overreacted. 
They interpreted the criticism as betrayal of the very victory the academics had assisted in winning as the analysts, interpreters of and activists in the movement of nationalism against colonial rule. Arrests, detentions and exile followed, turning campuses into war zones. In the last two decades the state has been against ideas and freedom of expression and inquiry. This resulted in fear, anger, and student rebellion raged, leading to the repeated closure of the institutions. The state set itself on revenge at every turn. In the process, students all but lost the original lofty ideals that had launched them on the freedom road. Domestic boycotts, sit-ins, the laying to waste of kitchens and toilets came to contain little more than a nuisance value. Sounds like home, doesn't it? (pp. 215-216).

This extract sounds like a 'cautionary tale' and it speaks of a world hemmed in by intolerance of dissent and characterised by paranoia on the part of those who have been entrusted with leadership responsibilities in our country. Mphahlele was an itinerant scholar. His worldwide travels had provided him with invaluable firsthand experience of the erosion of democratic ideals after the attainment of independence in some of the countries he had lived in. He therefore spoke from an informed position. Not only were his concerns valid: They were prescient. We ignore them at our own peril. In what can be safely regarded as his final gift to Africa and the world - a book entitled, There Was a Country, Chinua Achebe (2012) counsels us:

But there is a moral obligation, I think, not to ally oneself with power against the powerless. An artist, in my definition of the word, would not be someone who takes sides with the emperor against his powerless subjects. (pp. 58-59).

Throughout his life, Mphahlele consciously chose not to 'take sides with the emperor against his powerless subjects', to cull a phrase from Achebe. Achebe (2012) further enlightens us:

My own assessment is that the role of the writer is not a rigid position and depends to some extent on the state of health of his or her society. In other words, if a society is ill, the writer has a responsibility to point it out. If the society is healthier, the writer's job is different. (p. 57)

Mphahlele was highly sceptical of Christianity, partly because of its perceived collusion in the conquest, disinheritance and subjugation of indigenous African people - and his discordant relationship with Christianity can be traced back to his celebrated work, Down Second Avenue (2004), where he writes:

It never seems to have occurred to the church that under its nose has been growing a calculating white barbarism, among those it considered as hereditary custodians of Christianity. Custodians who need mission stations in their very midst. I cannot but reaffirm what I said in a B.B.C. talk in 1955 on the African intellectual: that to us, the church has become a symbol of the dishonesty of the West. I'm still suspending belief and disbelief as far as the necessity or uselessness of organised religion goes. All I know is that I found no use for it in South
Africa; that since 1947 when I stopped going to church, I have become progressively weary of all the trappings of mystical formalism that go together with South African 'Christianity'. For the moment, I'm content to move on, free of this sort of allegiance, exposing myself to the impacts of as many ways of life as possible. I'm glad that I can at last exercise that right. (p. 211).

Mphahlele was not the first black writer in South Africa to launch an attack on Christianity - an attack that was based on lived experience. Before him, S. E. K. Mqhayi (1943) also had crafted a poem exposing the inherent contradictions of Christianity - a poem entitled 'AA! Hail The Hero of Britain', whose argument partly runs thus:
You come with a preacher assisted by a soldier;
You come with gunpowder and bullets;
You come with cannons and guns - which burned - like knees
Please forgive me O God, but whom should we obey?
Go past, Calf-of-the-big-animal,
Trasher-with-the-feet, trashing us for a long time already!
Come past us and go nicely back,
You who feast on the inheritance of my country.
(Mqhayi 1943)

As we celebrate his legacy, I would like to quote fragments from his lesser known work, a poem entitled, 'To You My People' (Mphahlele 1984b), which speaks to his stance on Christianity. The poem was published in the literary journal New Classic, which is now out of print:

Whilst I'm on my sickbed
Whilst I'm on my deathbed
I want no christian hymns:
they come from abject hearts
drained of joy,
from soul-eroding guilt
and fear of death.
Save your hymns -
at best they devastate me
with their sadness
unredeemed;
they come from church
where singers only take
their wretched souls and miseries to God
and not their strengths and beauty.

This is not an anti-God poem, nor is it a diatribe or an act of desecration. It is a poem that speaks about broken trust, and, by extension, the corruption of Christianity in order to serve narrow sectarian interests. Mphahlele's rejection of Christianity and all it stands for is palpable in the following stanza:

Keep away from me those hebrew folktales testaments about the love of an angry god we slavishly recite to entertain each other while the whiteman holds us hostage. Save me from your dead-end prayers, Give me freedom songs

in many tongues give me drums and whistles 
let me hear your bodies shuffle

to the song of Africa

Footnote: The word 'hebrew' is written in small letters throughout the poem.

He seems to question the authenticity and sincerity of Christianity; he also seems to regard it as a form of drama, as the word 'entertain' signifies. But this poem also seems to have the tone of a will which is essentially a blueprint for his burial:

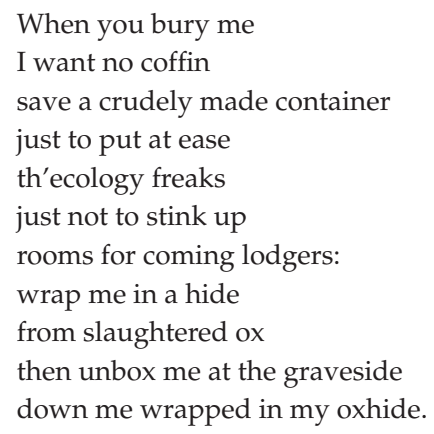

Here he seems to be arguing for a return to the source - a return to African burial traditions and rituals. Could this be a rejection of modernism and its formalism? Maybe. Mphahlele (1987) fully embraced Africa, its beauty, its landscape, culture and traditions long before it became chic to do so. The following stanza is equally instructive:

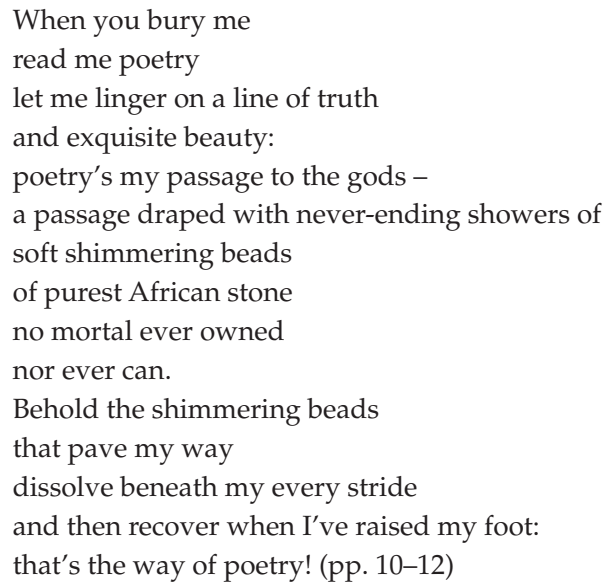

This stanza is well crafted. Embedded in it is Mphahlele's death wish, the reading of poetry at his funeral - and what a grand send-off this would be! It would indeed be a fitting send-off for a man who had spent his lifetime in the realm of the work of the mind: writing, writing and spreading the gospel of African literature all over the world. In his address entitled, 'Poetry and Humanism: Oral Beginnings' (1986), he advances the following argument on the pivotal role of poetry in African Tradition:

I must repeat, in the light of the foregoing, that the African's traditional habit of mind that gathers together man, external nature, ancestral presences, the Vital Force or Supreme Being that inhibits and give meaning to these relationships, all into organic whole - this habit of mind is the creative principle itself. Because poetry lives in the relationship between beings, alive and alive-in-death, things, time and space, and in the essence of this network, establishing connections in a beautiful because powerful language. To make poetry is to be authentically human. To be such is also an affirmation that I am because we are, we are because you are. (p. 13)

His forthright critique of Christianity is also embedded in the following excerpt from the address cited above:

The Christian Gospel could not mediate effectively for the process of mutual recognition because its messengers were full of themselves, and full of contempt for the African's thought and belief. By the time Christianity had eventually spread, slavery, and later colonialism had damaged relations between the strangers and the indigenous inhabitants. (p. 23)

Mphahlele's stance on Christianity in the poem is plausible and is based on tangible, verifiable evidence. It is earlier advocates and adherence's failure to recognise and accommodate other world views or other forms of consciousness is a glaring weakness. It failed to unify disparate, contending world views in Africa as Chinua Achebe shows in his classic, Things Fall Apart. Throwing more light on Mphahlele's vision of Afrikan Humanism and Christianity Rafapa (2007) asserts:

One of the building blocks of Afrikan Humanism, according to Mphahlele, is a sort of postcolonial hybridity in which traditional African religious tenets refuse to die. Similarly, because colonialisation came with Western Christianity, the imported trope of Christianity from the European colonisers remains one of the major features of religious practice among Africans today. According to him, the immensity of the challenge faced by Africans to manage postcolonial hybridity in an empoweringly self-defining manner is evident in divisions among Africans in the extent to which they embrace Western Christianity and other imported lifestyles in an uncritically mimicking manner. Father Come Home is one of Mphahlele's novels in which the intersection of these two conflicting religions and its effects on African communities is explored in artistically and theoretically dexterous ways. (p. 95)

One of Mphahlele's remarkable contributions to intellectual is his advocacy for a philosophy he called African Humanism (also Afrikan Humanism). In a lecture entitled 'Poetry and Humanism: Oral Beginnings' (1986), which was part of the Raymond Dart Lectures (Lecture 22), he offers the following insights:

There are a variety of philosophical and ideological doctrines that claim humanism as their basic impulse, both as process and as final destination of mankind. For instance, Marxism and Communism will claim that they are out to rescue man from the self-alienation that capitalism and private enterprise drive him to; Protagoras' pragmatism will assert, 'man is the measure of all things'; Personalism or spiritualism will claim that man is capable of perceiving transcendental reality; the mystic will say that he does not need any intercessor between himself and his god-he is capable of perceiving God's powers; every religion 
will claim that it is the Way to man's happiness on earth and ultimate salvation, no matter how narrow or thorny. The existentialist will affirm that the universe of 'human subjectivity' is the only one there is, you're on your own, in other words. All the time. (p. 1)

And he continues:

African humanism is not a philosophical contention that has been argued. It has never been a subject of analysis, but we have ample evidence of it as a way of life. The African lives it and does not stand outside it to contemplate the process. It is deeply embedded in our proverbs and aphorisms and oral poetry, and in the way our elders spoke to us, and their children passed on the wisdom. (p. 10)

Mphahlele (1986) concludes his lecture by highlighting the sort of challenges that militate against the flourishing of African Humanism in South Africa - challenges whose basis is a skewed approach to race relations and an inability to deal creatively with difference:

The final question for me, one that always sticks in my gullet, is what do we do with white people in this country who programme and process our lives and support the ideology that frustrates our humanism and the best there is in theirs? You cannot educate or civilize a person who believes he is superior to you, refuses to be refined, supports tacitly or overtly the system that shuts us out of his world of privilege and rights and thereby shuts him in. So, if anybody is excluded from African Humanism, traditionally an inclusive philosophy, they have themselves willed it so.

Wash your hands before you and I eat out of my bowl something you have not even aligned to concede to me in 300 years. (p. 25).

In an article entitled, 'Es'kia Mphahlele: “Father Come Home"', Muthal Naidoo (1984) portrays African Humanism as a motif that pervades Mphahlele's novel, Father Come Home - not only that: she also highlights the tenets that underpin it such as belief in the Supreme Being and the Ancestors and Family and Social Relationships:

Es'kia Mphahlele believed that the regeneration of African consciousness is essential to real African development and progress. African consciousness arises from the norms and values inherent in the traditional way of life. These values were marginalised under colonialism and apartheid when African people were forces to adopt Western norms and values. As a result, they developed a divided consciousness and became spiritually and psychologically weak. In order to regain the pride, dignity, strength, and independence of the African spirits, it is necessary to return to the traditional values. As African people have lost the context that gave rise to these values, regeneration of the African consciousness now depends on the formal articulation of traditional values. And this is what Es'kia Mphahlele has provided in his philosophy of African Humanism. In his articles he sets out the tenets of African Humanism and in his stories and novels he illustrates the struggle to maintain African values. A study of his writings, therefore, will lead to an understanding of humanism that is essentially African. (Mphahlele 1984c).
In an illuminating essay entitled, 'Es'kia Mphahlele's etching of two axes of religion using the framework of his concept of African Humanism in Father Come Home', Lesibana Rafapa (2007) asserts:

The distinctive African identity is the central focus of Mphahlele's theory of Afrikan Humanism faced many imperialist threats against its preservation in the past through colonialisation and apartheid, yet survived. His concept of Afrikan Humanism dialectically drew on the heritage of 20th century Pan Africanism and black Consciousness ideologies of the 1930s and 1940s, as well as later debates among African theorists on issues of essentialism, racism, ethnocentrism and monocentrism. Mphahlele regards cultural resilience and forward-looking hopefulness about collective cultural survival of distinctive Africanness to be an aspect of his theory of Afrikan Humanism. Though in a non-essentialist way but in ways bearing testimony to separate historico-geographic, experiences between Europeans and Africans, Mphahlele regards the consiousness and lifestyle he defines as Afrikan Humanism culturally to distinguish Africans from nonAfricans. (Rafapa 2007)

Mphahlele had a lifelong commitment to teaching and by extension the classroom environment. It is his profound love and passion for teaching and good quality education that led to his being banned from it because of his vociferousness against the imposition of Bantu education to African children in South Africa. It is also his love for teaching that influenced his return to South Africa in 1977 a decision that was not taken lightly as the following extract from his autobiography, Afrika My Music (Mphahlele 1984a), illustrates:

The politics? What was the worst that could happen? If our minds dwelt unduly on that, then it would be no use thinking of returning any longer. There are people living here-that was the immediate answer. It sufficed. We wondered what would be the best for the two dependent children, Chabi (going on eighteen) and Puso (going on seventeen)? It would be unfair to expose them to South African conditions, now that they had become cosmopolitan... Looking at the English syllabus I was sure that a good teacher - and I am vain enough to consider myself a born teacher - could inject life and new ideas into it... I was confident that if given the opportunity I and others could devise a way of getting freshmen students off to a better start. (pp. 182-183)

Returning home to South Africa, he had not anticipated the nature and magnitude of the sort of impediments that would dog his re-entry into his lifetime passion, education, as the University of Pretoria experience which he recounts in Afrika My Music (Mphahlele 1984a) shows:

The English language press championed my cause when I lost the Sovenga post. Government officials refused to answer their questions. The university administration Rector and all let it be known that the then Minister of Education and Training had turned down its unanimous decision to appoint me. The Minister refused to give me reasons. He promised, though, that he would veto any appointment Ezekiel Mphahlele might be given by any university administration came out with at last: It was not the policy of the central government to let Blacks chair departments like English. (p. 5) 
This kind of experience and prejudice could have come as a disappointment to Mphahlele who wanted nothing more than to make a contribution to his country - but it also could have strengthened his commitment and resolve to his lifelong passion, teaching.

Not even 20 years of being in exile in different parts of the world would disentangle him from what he characterised as 'the tyranny of place: - the sort of hold and magneticism that your home or cultural roots have on you' as the following extract from Afrika My Music shows:

The bonds that have held us to the original African experience though have remained intact during our travels. We still feel a strong identity with our ancestors: The living dead who are the spiritual dimension of our reason for returning. Come back native son, native daughter come back (p. 9)... The tyranny of time, the tyranny of place... The muck, the smell of it, the fever and the fight, the cycles of decay and survival... and 'the sounds begin again' I want daytime, I want place, I want a sense of history. Even though place will never be the same again for me, because its lights and shadows may change, I want to be there when it happens. (Mphahlele 1984a:11)

In Chabani Manganyi's (1983) biography, Exiles and Homecoming: A Biography of Es'kia Mphahlele, Mphahlele asserts that his return to apartheid South Africa was no mere convulsion - it was an impulse that had been in his psyche or consciousness for quite some time:

The return to the painful South Africa has been many years in the making. Even as I and my family wandered through Africa, Europe and America we carried the prospect of return as a selffulfilling prophecy. (p. 11)

The return to the painful South Africa has been many years in the making. Even as I and my family wandered through Africa, Europe and America we carried the prospect of return as a selffulfilling prophecy. (p. 11)

The 'tyranny of place' here is projected as an irrepressible, resilient and unconquerable phenomenon - a phenomenon that cannot be deferred forever.

\section{Conclusion}

The preservation and celebration of Mphahlele's ideals is a national project that cannot be left entirely in the hands of the Es'kia Institute. University departments that teach literature also have a moral and ethical obligation to help advance them. Anything less than that on their part would amount to betrayal, self-negation and self-inflicted disinheritance. In the blurb to Mphahlele's collection of essays entitled Es'kia, Professor Mbulelo Vizikhungo Mzamane (2001) offers the following insights on Mphahlele's remarkable literary career:
For more than half a century, Es'kia Mphahlele has infused in his readers his deeply humanistic vision and critical consciousness. His collected work portrays the paradox that is the modern African personality: 'detribalised and westernised, but still African'. Mphahlele's remarkable erudition, powers of articulation, incisive mind, insight, integrity, pleasant disposition and sense of humour - all make him a true icon of modern African letters.

His deeply humanistic vision, critical consciousness and relentless advocacy for African literature are an integral part of his rich legacy. It is incumbent upon us in the academy to continue to celebrate and carry forward his vision splendid.

May his legacy live on. He kept the faith. He made a way where there was no way - a true pioneer.

\section{Acknowledgements Competing interests}

The author declares that he has no financial or personal relationships which may have inappropriately influenced him in writing this article.

\section{References}

Achebe, C., 2012, There was a country, Penguin, London.

Asein, S.O., 1980, 'The humanism of Ezekiel Mphahlele', The Journal of Commonwealth Literature 1(xv), 38-49. http://dx.doi.org/10.1177/002198948001500105

Hutchinson, A., 2006, Road to Ghana, Penguin Books, London.

Manganyi, C, 1983, Exiles and home comings, A biography of Es'Kia Mphahlele, Ravan Press (Pty) Ltd, Braamfontein.

Mphahlele, E, 1962, The African image, Faber and Faber, London.

Mphahlele, E., 1967, Voices in the whirlwind and other essays, Hill and Wang, New York.

Mphahlele, E, 1971, The Wanderers, Fontana, London.

Mphahlele, E., 1980, Chirundu, Nelson, Walton-on-Thames.

Mphahlele, E., 1984a, Afrika my music, Kwela Books, Cape Town.

Mphahlele, E., 1984b, 'To you my people', New Classic 1.12 (1987), 10-12.

Mphahlele, E., 1984c, Father come home, Ravan Press, Johannesburg.

Mphahlele, E., 1986, Poetry and humanism: Oral beginnings', Rymond Dart Lectures, Lecture 22, Witwatersrand University Press, Johannesburg.

Mphahlele, E., 2004, Down second avenue, Picador Africa, Johannesburg.

Mphahlele, E., 2005, Es'kia Continued, Stainbank and Associates, Johannesburg.

Mqhayi, S.E.K., 1943, AA! Hail the Hero of Britain, Witwatersrand University Press, Johannesburg, viewed 02 August 2008, from http://www.poetryinternationalweb. net/pi/site/poem/item/13286

Mzamane, M.V., 2001, Blurb for Es'kia, Kwela Books, with Stainbank and Associates Johannesburg.

Naidoo, M., 1984, 'Es'kia Mphahlele': Father come home, Ravan Press, Johannesburg, viewed 23 May 2016, from http://www.muthalnaidoo.co.za/.../290-eskiamphahlele-father-come-home

Ndebele, N.S., 2008, 'Es'kia Mphahlele: “Writer, teacher, and teller of truth”', Sunday Times, November, p. 34.

Rafapa, L., 2007, Es'kia Mphahlele's etching of two axes of religion using the framework of his concept of Afrikan humanism in father come home, viewed 15 May 2016, from http://www.letterkunde.up.ac.za/argief/44_2/06\%20Rafapa\%20 03.pdf

West, C., 1993, Race matters, Beacon Press, Boston, MA. 